\title{
Community Communication Forum (FKM) \& WhatsApp (WA) Group: Dialogic Communication between Company-Community in Achieving Community Development in Indonesia
}

\section{Adhianty Nurjanah}

Communication Dept, Yogyakarta Muhammadiyah University, Indonesia

\section{Abstract}

Independent Waste Bank is a program of Corporate Social Responsibility (CSR) PT Holcim Indonesia Tbk. Cilacap Plant as a form of participation of companies in tackling the garbage problem in Cilacap. This paper reports on a case study of CSR program of Independent Waste Bank PT Holcim Indonesia Tbk. The results show that the pattern of dialogic communication between the company and the community through Community Communication Forum (FKM) and utilization of Information and

Corresponding Author: Adhianty Nurjanah; email: adhianty@umy.ac.id

Received: 09 April 2017 Accepted: 17 May 2017 Published: 12 June 2017

Publishing services provided by Knowledge E

(c) Adhianty Nurjanah. This article is distributed under the terms of the Creative

commons Attribution

License, which permits unrestricted use and redistribution provided that the original author and source are credited.

Selection and Peer-review under the responsibility of the ICoSaPS Conference Committee.

\section{S OPEN ACCESS} Communication Technology (ICT) in the form of WhatsApp (WA) Group is capable of generating a positive relationship and be able to produce a chance to achieve unity in the difference between the company and the community. The CSR program managed to develop and empower local communities by promoting self-reliance and creativity, and consequently improve the welfare of the local community.

Keywords: Waste, Dialogic Communication, Corporate Social Responsibility (CSR), Community Development

\section{Background}

Proper waste disposal is one of the problems of development in Cilacap. This is because the ratio of waste tonnage produced per day compared to the number of garbage trucks is imbalanced. In a day, the volume of waste in the city area of Cilacap district reached 646.5 cubic meters of waste, which is equivalent to approximately 92 truckloads of garbage [2]. The increasing number of Cilacap district residents followed by their consumption patterns have led to increased daily waste volume and more diverse types of waste such as hazardous packaging waste that are not easily decomposed by natural processes. As a result, there are accumulations of garbage that cause odor, which then reduces the level of soil fertility and inhibit circulation of soil, waterways and ultimately damage the environment. 
One private company in Cilacap, Central Java, which since 2001 until today, which has implemented a Corporate Social Responsibility (CSR) program is PT Holcim Indonesia Tbk. Cilacap Plant to tackle the garbage problem in Cilacap. Independent Waste Bank CSR program is located in the Family Empowerment Post (Posdaya) RW X Ketapang Peace Village Kebonmanis North Cilacap regency, Central Java. The principal activities of program Independent Waste Bank is to promote recycling, where people sort their household garbage according to its type, then collected and sent to the bank to be weighed and the results are then incorporated into the passbook.

\subsection{Community Development and Corporate Social Responsibility (CSR)}

Phillips and Pittman [9] assert that community development is intended to build capacity. In another part, it is submitted that "community development builds the capacity of a people when they encourage or teach others to create reviews for their own dreams, to learn new skills and knowledge. That community empowerment is intended to build the capacity of communities, and encourage or teach others to make their own dreams come true, to learn new skills and knowledge. "The general objective of community empowerment in national development is to empower specific groups in society socio-economically. Thus, they can be more independent, able to meet the basic needs of their lives, and are able to participate in community development.

Community empowerment as a process of community development has a sphere of community empowerment, which according to ([6]: 129-136) consists of the following: (1) Human Development as the first and foremost effort in community empowerment based on the understanding that the purpose of development is to improve quality of life or well-being. In this case, the Human Development includes the strengthening or development of human capacity, (2) Business Development is an important effort in each empowerment and as a result of human development that can provide benefits for welfare improvement so as to obtain support in the form of community participation, (3) Community Development which consists of the physical environment and the social environment. In this case, the social environment also plays an important role in determining the sustainability of business and life, (4) Institutional Development is a form of healthy institutional social relations and their very instrumental in the success of community empowerment process. Thus, through community empowerment program, the community that once was not economically, socially and ecologically empowered becomes even more empowered, having the 
strength and ability so that they can become agents of change in the national development.

Their demands and the increasing awareness of the company is associated with the obligation of corporations to be socially responsible and be ethical in its business. The concept of Corporate Social Responsibility (CSR) has become an integral part to today's major corporations. CSR is essentially the need for companies to be able to interact with the community as a whole to adapt and to obtain social benefits in the form of trust ([10]: 1). olstated that CSR is a commitment to improve the welfare of society as a consideration of business practices and contributions of the company's resources. The core of this definition does not refer to a business activity that is governed by the legislation in force, but rather on the voluntary commitment of companies that have been selected and implemented in its business practices.

\subsection{Dialogic Theory on Relationships (Relational Dialogic Theory)}

In discussing the relationship that is created from effective communications being built then the Dialogic Theory on the relationship (Relational Dialogic Theory) becomes important.

In the book, Little John ([4]: 303-307), Leslie Baxter states a theory about relationships that provide vantage points to view the dialogue process. The points are:

(a) Relationships generated through dialogue: In the first view of this theory, it is in the dialogue that you define your relationship with others. Your ideas about yourself, other people and relationships formed in the talks. Even when you retell old stories of the relationship, or shared experiences which bring togetherness. Baxter refers to this as chronotopic similarity, at the same time you will recognize the difference between you and the other person in the relationship. Baxter dialogic theory says that relationships are generated through a dialogue among noises. Different voices are integrated in a conversation. According to Baxter, the dialogue is a conversation that defines and redefines the relationship when the relationship appears in the actual situation. Relationships generated through dialogical communication processes are dynamic and can adjust the similarities and differences. Actually, the relationship unites us through equality, while a relationship also creates, maintains and regulates areas of difference.

(b) Dialogue generates an opportunity to achieve unity in diversity: Through dialogue we govern the dynamics of influence between the centripetal force and centrifugal-force that separates and draws us altogether, the power that creates an understanding of chaos and force that gives a sense of togetherness. These 
opposing forces are dialectical in the sense that they involve a tension between two or more elements of a system opposition and the relationship provides a context in which we organize opposition.

(c) Dialogue is the aesthetic: Aesthetics involves an understanding of the balance, alignment, shape and unity. Dialog provides a relationship identity, uniqueness and unity. The character of a relationship becomes such reflection of the aesthetics created in dialogue. Communication in a relationship can form a sense of unity through a dialogue.

(d) Dialogue is a discourse: Baxter noted that the relationship was never in the form of a series of statements of a single person but a process that runs back and forth over time. Therefore, the actual conduct or practice is important where the actors are involved throughout the relationship course. In theory, the idea of a relationship is very important because the relationship is not something you think cognitively in your head, but is the result of the discourse.

\section{Method, Findings, and Discussion}

This descriptive study of Cilacap's CSR program basically involves a review of its program activities that are accessible through its website, and interviews with the stakeholders.

Community development in managing wastes through the Independent Waste Bank program of PT Holcim Indonesia Tbk. Cilacap Plant is done by the utilization of communication and information technology. One of the utilizations is by using WhatApp Group as the communication between the company and the community. Through the WhatsApp Group medium, the company can dialogue with the community and mediated by the staff of Independent Waste Bank. This WhatsApp Group discusses matters related to the necessities of the community in the management of Independent Waste Bank, for example the significance of capacity improvement on the staffs of Independent Waste Bank through certain training program. In the communication technology utilization using this WhatsApp group the community is represented by the staffs of Independent Waste Bank and then they are able to do dialoguing personally with PT Holcim Indonesia Tbk. Cilacap Plant through the field assistant staffs.

In addition, the communication between company and the beneficiaries of Independent Waste Bank through Community Communication Forum (FKM), is done regularly from the level of Independent Waste Bank group, at village and regency level. The 
process of communication is done through Focus Group Discussions involving the community and government at district and village level of Cilacap Regency. In the Community Communication Forum (FKM) the participants expressed the opinion / feedback verbally and in writing about the various constraints and obstacles encountered in the implementation of programs that have been realized. Additionally, the public express their opinions on the proposed development strategies or program implementation Independent Waste Bank. As stated by Mrs. Susi I of the Staff Community Development PT Holcim Indonesia Tbk Cilacap Plant: "Through FKM we communicate by means of dialogue with the public so that we can understand what become the needs of society, so that the CSR program we do actually provide benefits and is in accordance with their aspirations". In addition, we also have WhatsApp (WA) Group in which we can communicate directly with all members and staffs of the Independent Waste Bank, we have a really close relationship".

FKM and WhatsApp Group is where the company interacts with the stakeholders' dialogue to increase the understanding of stakeholder expectations. As stated by $\mathrm{Mr}$. Moh. Nurhidayat: "We can dialogue face to face (directly) with PT Holcim through Community Communication Forum (FKM), so they knew we needed especially in the Independent Waste Bank CSR program" In addition now we have a WhatsApp (WA) group which is the communication between us and PT Holcim so if there are any obstacles concerning the activities of the Independent Waste Bank can be responded quickly without having to wait for the Community Communication Forum that has limited time."

In the implementation of Independent Waste Bank CSR programs, the CSR communication between the company and the community is established through the Independent Waste Bank Community Communication Forum (FKM). FKM is a means of two-way communication between the company and beneficiaries of CSR programs. It also aims to evaluate the performance of CSR programs that have been conducted by PT Holcim Indonesia Tbk Cilacap Plant. FKM is held half-yearly in each sub-district and then performed at the district level. The purposes of the implementation of the FKM are to be a means of CSR communication between the company and the beneficiaries, a means of delivering the aspirations and the assessment of community's needs which is used as the basis for upcoming CSR Program.

The utilization of WhatApp Group also plays a significant role in the creation of dialogic communication between the company and the communities. This is done continuously and sustainably so as to minimize the differences of opinion; especially about how important it is to manage waste in the household. The initiation of the Independent Waste Bank CSR program is in 2012, there are many people who refuse to follow this development, empowerment program with troublesomeness as the excuses and 
they were not convinced that the normally discarded garbage shall be managed in a manner of being sorted out and then saved to be reused. Through the dialogues executed continuously, in the end the public is increasingly aware of how to recycle the waste. To date the Independent Waste Bank CSR program has made continuous innovation so the Waste Bank does not only do the main course that is waste recycling, but it has the microeconomic business activities that can improve the the family economy such as micro-enterprises in the form of garbage stalls, laundry, handicraft business Innel Creative Handicraft Recycling which is a garbage craft center that has economic value.

The process of CSR communication for social change emphasized on how the information is spread, how are the efforts to obtain information being driven, how trust is built; among community members and by community members. Additionally, the CSR messages that are created, sent, received and responded to by the people, should be a part of a process of listening to the needs of society as a two-way communication through dialogue.

As for the answer to the needs of society in the form of communication messages created will be able to drive the behaviors or attitudes, raise awareness and understanding of the issues that exist in society, create social awareness, foster a sense of shared responsibility to improve the overall quality of community/social life as a whole. Thus, the process of communication for social change must be created and developed, and is geared to develop, empower communities and create social change or advancement of people's lives in a sustainable manner as well as the Independent Waste Bank CSR program to change the paradigm of people from littering into trash saving.

The principal activities of Independent Waste Bank are waste recycling and disposal activities, where people sort their household wastes each according to its type then the wastes are collected and sent the waste to the bank to be weighed and the results are incorporated into the passbook. The Independent Waste Bank CSR Program of PT Holcim Indonesia Tbk. Cilacap Plant, has been able to empower them with the process of development activities that are:

(1) Human Development: Community development in the field of Human Development is done through quality improvement program of Human Resources by providing knowledge, insight and experience to the management of Independent Waste Bank CSR Program. The activities are conducted by organizing a training program for the managers of Independent Waste Bank CSR program on organic and inorganic waste management, manufacture training of handicrafts made of plasticpaper, Motivation Training, Leadership Training and Comparative Study studied 
together at the Gemah Ripah Waste Bank in Bantul Regency, Yogyakarta. As we all know, that the managers of Independent Waste Bank CSR program are mostly housewives who initially did not have the skills in the field of waste management. Thus, through the human development community empowerment program it is expected that the citizens especially the managers can improve their capacity of knowledge, insight and experience.

(2) Business development: Results of human development that is given to the public, generating a positive development for Independent Waste Bank CSR Program for now it is not only savings unit which manages waste but other micro business units such as garbage stalls, Laundromat, and even home craft business Innel Recycling Creative Handicraft which is a trash craft center unit being very financially supportive towards the income of the household economy. As presented by Mz. Rustono: "Mothers in this neighborhood are now very productive and have their own income from junk made crafts such as flowers, bags, plastic grocery etc., so they can help their families economically at least, can meet their own needs and can add an allowance for her children" (Interview of Mz. Rustono, February 20, 2016).

(3) Institutional Development: The development of institutions by providing assistance, facilities, support and institutional strengthening through training, mentoring. (4). Community Development: The Independent Waste Bank CSR Program gives out positive impact for clean environment with the Independent Waste Bank CSR Program, the public is increasingly aware of the importance to have clean and healthy life behavior (PHBs) that can be created from family."Independent Waste Bank CSR Program gives positive impact on the environment, the environment becomes clean and healthy, not a lot of rubbish strewn anymore because people are aware and in the family now there seems to be "titen" culture in observing trash carefully, sort them especially for inorganic waste (plastic, cans, bottle caps, newsprint, etc.) then collect the waste to be deposited in the Independent Waste Bank" (Interview with Mr. Moh Nurhidayat, February 20, 2016).

Finally, to promote the process of moving from one strategy to the other, it is suggested to structurally strengthen and tie the corporate communication to strategic management. FKM and the utilization of ICT in the form of WhatsApp (WA) Group is a dialogical form of communication between the company and the community to build positive relationships and create a common vision and common goals. 


\section{Conclusion}

Independent Waste Bank CSR Program has been able to develop, empower people through inorganic waste management and is able to change the paradigm of people from littering into a trash saving. FKM and the utilization of ICT in the form of WhatsApp (WA) Group is an effective means of communication in both directions (dialogical communication) between the company and beneficiaries so Independent Waste Bank CSR program can be accepted and implemented in a participatory manner by people, particularly in Kebon Manis Northern Cilacap District.

FKMand the utilization of WhatsApp group communication medium is the interaction strategy of communication of CSR which suggests two-way communicative processes the company can stage and encourage to enhance stakeholder dialogue and hereby increase the understanding of stakeholder expectations, so effective dialogic communication between the company and the communities can be created towards the realization of community development and empowerment particularly in the management of inorganic wastes through the Independent Waste Bank CSR Program in Cilacap Regency Indonesia.

\section{References}

[1] Cresswell, J. W. 2009. Research Design: Qualitative, Quantitative and Mixed Approach. Third Edition. Pustaka Pelajar. Yogyakarta, p. 145.

[2] Documents of Waste Bank Independent, 2014, CSR Program PT Holcim Indonesia Tbk. Cilacap Plant.

[3] Engkos, Koswara. 2010. Penelitian Pers dan Komunikasi Pembangunan Volume 13 No. 3 Febuari 2010.

[4] Littlejhon, Stephen and Karen A.Foss, 2008, Theories of Human Communication Ninth Edition, Lyn Uhl Publisher, United Stated of America, p. 303-307.

[5] Kotler, P. and Lee, N. (2006). Corporate social responsibility: doing the most good for your company and your cause.

[6] Mardikanto, T. 2010. Concept-Concept Community Development, Community Development, Post Graduate Program. Surakarta : UNS Press, p. 129-136.

[7] Moleong J, Lexy. 2001. Qualitative Research Methodology. Remaja Rosdakarya. Bandung, p. 103.

[8] Nazir, Muhammad. 1988. Research Methods. Ghalia. Jakarta, p. 63.

[9] Phillips, R. Pittman, R. H., 2009. An Introduction to Community Development. Routledge, London \& New York. 
[10] Rudito, Bambang and Famiola Melia. 2013. CSR (Corporate Social Responsibility), Rekayasa Sains. Bandung. p. 1.

[11] Sutopo, H. B. 2002. Qualitative Research Methodology Basic Theory and its Application in Research, Sebelas Maret University Press, Surakarta, p. 186.

[12] Tahoba. 2011. Communication Strategy for Community Development, Case program Community Development in Indigeneous Communities Directly Affected by The LNG Tangguh Project Around Bintuni Regency West Papua. Proceeding_Permana_2011 in http://www.google.com/url?paparisa.unpatti.ac.id, downloaded on February 2, 2016. 